....... Sinković, Govorčin, Sedlar: Usporedba fizikalnih svojstava neobrađene i toplinski...

\title{
Usporedba fizikalnih svojstava neobradene i toplinski obrađene bukovine i grabovine
}

\section{Comparison of Physical Properties of Untreated and Heat Treated Beech and Hornbeam}

\author{
Prethodno priopćenje • Preliminary paper \\ Prispjelo-received: 14. 6. 2011. \\ Prihvaćeno-accepted: 22. 11. 2011. \\ UDK: $630 * 812.23 ; 630 * 812.3 ; 630 * 812.463$ \\ doi:10.5552/drind.2011.1118
}

\begin{abstract}
SAŽETAK • Istraživanjem fizikalnih svojstava toplinski obrađene bukovine i grabovine utvrđeno je da je njihova srednja vrijednost manja i signifikantno se razlikuje od srednjih vrijednosti fizikalnih svojstava neobrađene bukovine i grabovine. Srednja vrijednost gustoće u apsolutno suhom stanju toplinski obrađene bukovine manja je za 8,5\% od neobrađene, a za grabovinu je ona manja za 7,5\%. Smanjenje srednjih vrijednosti maksimalnih utezanja toplinski obrađene bukovine i grabovine u odnosu prema neobrađenoj još je veće. Maksimalno radijalno utezanje toplinski obrađene bukovine manje je za $7 \%$, maksimalno tangencijalno utezanje za 23,5\%, a maksimalno volumno utezanje za 19,3\% od istih fizikalnih svojstava neobrađene bukovine. Toplinski obrađena grabovina ima srednju vrijednost maksimalnoga radijalnog utezanja za $123 \%$, maksimalnoga tangencijalnog utezanja za $86 \% i$ maksimalnoga volumnog utezanja za 99,5\% manju od istih fizikalnih svojstava neobrađene grabovine.

Takvim smanjenjem maksimalnih utezanja u radijalnome i tangencijalnom smjeru toplinskom obradom grabovina postaje znatno prihvatljivija za izradu proizvoda za koje je važna dimenzionalna stabilnost.
\end{abstract}

Ključne riječi: fizikalna svojstva, toplinski obrađeno drvo, bukovina, grabovina

\begin{abstract}
The investigation of physical properties of heat treated beech wood and hornbeam wood found that their average value is lower and significantly different from average values of physical properties of untreated beech wood and hornbeam wood. The average value of density in absolutely dry condition of heat treated beech wood is smaller by $8.5 \%$ from the untreated, and the hornbeam wood is smaller by $7.5 \%$. Reduction of average values of maximum shrinkage of heat treated beech wood and hornbeam wood is even bigger in relation to the untreated wood. Maximum radial shrinkage of heat treated beech wood is smaller by 7\%, maximum tangential shrinkage by $23.5 \%$ and maximum volumetric shrinkage by $19.3 \%$ compared to the same physical properties of untreated beech wood. Heat treated hornbeam wood has an average value of maximum radial shrinkage smaller by $123 \%$, maximum tangential shrinkage by $86 \%$ and maximum volume shrinkage by $99.5 \%$ compared to the same physical properties of untreated hornbeam wood.

With such reduction in the maximum shrinkage in radial and tangential direction using heat treatment, hornbeam becomes particulary suitable for making products where dimensional stability is important.
\end{abstract}

Key words: physical properties, heat treated wood, beech wood, hornbeam wood

\footnotetext{
Autori su izvanredni profesor, izvanredni profesor i asistent Šumarskog fakulteta Sveučilišta u Zagrebu, Zagreb, Hrvatska.

${ }^{1}$ Authors are associate professor, associate professor and assistant at Faculty of Forestry, University of Zagreb, Zagreb, Croatia.
} 


\section{UVOD}

\section{INTRODUCTION}

Celuloza, hemiceluloze i lignin (Kollmann i Cote, 1968) tri su makromolekularne komponente od kojih je izgrađeno drvo. Reaktivne hidroksilne grupe u polimerima stijenki gradbenih stanica drva utječu na većinu kemijskih i fizikalnih svojstava drva. Iznosi utezanja koji utječu na stabilnost drva jedni su od njegovih bitnih fizikalnih svojstava. Toplinskom obradom drva smanjuje se utjecaj reaktivnih hidroksilnih grupa. U proteklim desetljećima mnogi su istraživači proveli istraživanja na tom području (Stamm, 1946, 1956; Stamm, 1964; Hillis, 1984; Rowell, 1983; Rowell, 1984; Kumar, 1994; Militz et al, 1997). Tjeerdsma et al. (1998) i Kotilainen (2000) također su proučavali utjecaj temperatura viših od $180{ }^{\circ} \mathrm{C}$ na kemijska svojstva drva. Na temelju promjene kemijskih svojstava dolazi, među ostalim, do smanjenja mase i higroskopnosti drva odnosno do povećanja stabilnosti dimenzija drva (Tjeerdsma et al, 1998; Kotilainen, 2000; Yildiz, 2002; Rousset et al, 2004). Uz te pozitivne učinke toplinske obrade drva nastaju i negativni koji se očituju smanjenjem mehaničkih svojstava drva (Yildiz et al, 2002). Veličina slabljenja mehaničkih svojstava drva ovisi o vrsti drva, maksimalnoj temperaturi i vremenu izloženosti drva visokoj temperaturi (Vernois, 2001). Navedena istraživanja pridonijela su mogućnosti široke industrijske primjene toplinske obrade drva (Bourgois, 1989; Rapp, 2001).

Bukva (Fagus sylvatica L.) je najzastupljenija vrsta drva u Hrvatskoj pa je zato potrebno proučiti fizikalna svojstva bitna za njezinu uporabu. Toplinska obrada bukovine, uz poboljšanje fizikalnih svojstava, omogućuje i ujednačivanje boje, doduše većinom smeđe, za dijelove bukovih stabala koji sadržavaju nepravu srž odnosno crveno srce. Time se povećava $\mathrm{i}$ iskoristivost sirovine.

Grab (Carpinus betulus) je zbog nekih svojih fizikalnih svojstava slabo cijenjena vrsta difuzno poroznih listača. Uobičajena je sličnost fizikalnih svojstava grabovine sa svojstvima bukovine, uz još veće iznose utezanja nego u bukovine. S takvim fizikalnim svojstvima grabovina je slabo iskorištena iako posjeduje specifična estetska svojstva. Toplinsk je obrada proces koji bi trebao omogućiti veću primjenjivost grabovine, uz gubitak specifičnih estetskih svojstava. Mogućnost šire primjene grabovine u drvnoj industriji i manja cijena grabovine kao sirovine mogli bi se povećati primjenom toplinske obrade.

\section{MATERIJAL I METODE}

\section{MATERIAL AND METHODS}

Istraživanje je provedeno na bukovini i grabovini. Od svake vrste drva uzeta je po jedna srednjača dužine dva metra, a sredina te piljenice nalazila se na prsnoj visini. Srednjače su izrađene od stabala s područja Papuka i iz iste gospodarske jedinice, što znači da su stabla imala i jednake uvjete rasta. Srednjača je u poprečnoj ravnini prepiljena na pola i dio ispod prsne visine uzet je za izradu uzoraka recentne bukovine $\mathrm{i}$ grabovine. Dio piljenica iznad prsne visine toplinski je obrađen na temperaturi $200{ }^{\circ} \mathrm{C}$, uz ukupno vrijeme trajanja procesa od 72 sata od početka zagrijavanja do hlađenja industrijske komore. Vremensko razdoblje u kojemu je drvo bilo na $200{ }^{\circ} \mathrm{C}$ iznosilo je 48 sati.

Nakon završetka procesa toplinske obrade od piljenica su izrađeni uzorci za ispitivanje fizikalnih svojstava drva. Uzorci su izrađivani od piljenica s mjesta od prsne visine prema žilištu i krošnji kako bi položaj uzoraka u piljenicama odnosno deblu bio što sličniji za obje grupe uzoraka. U trenutku ispitivanja fizikalnih svojstava sadržaj vode u uzorcima neobrađene bukovine i grabovine iznosio je $11 \%$, a u uzorcima toplinski obrađene bukovine i grabovine $4 \%$.

Ispitivanja fizikalnih svojstava - gustoće nakon potapanja, sadržaja vode nakon potapanja, gustoće u apsolutno suhom stanju, maksimalnih utezanja u radijalnome i tangencijalnom smjeru te maksimalnoga volumnog utezanja - provedena su prema važećim Europskim normama.

Statistička obrada i testiranje signifikantnosti razlike srednjih vrijednosti uspoređivanih svojstava neobrađene i toplinski obrađene bukovine i grabovine obavljeno je Mann-Whitneyevim testom, uz pomoć računalnoga statističkog programa Statistica.

\section{REZULTATI I DISKUSIJA 3 RESULTS AND DISCUSSION}

Statističke vrijednosti rezultata istraživanja fizikalnih svojstava neobrađene i toplinski obrađene bukovine prikazane su u tablici 1 .

Srednja vrijednost gustoće nakon potapanja neobrađene bukovine, kao i sadržaja vode nakon potapanja, veća je od gustoće nakon potapanja i sadržaja vode nakon potapanja toplinski obrađene bukovine. Srednje vrijednosti obaju svojstava neobrađene bukovine signifikantno su veće od srednjih vrijednosti toplinski obrađene bukovine prema Mann-Whitneyevu testu.

Srednja vrijednost sadržaja vode nakon potapanja neobrađene bukovine veća je za $15,4 \%$ od srednje vrijednosti sadržaja vode nakon potapanja toplinski obrađene bukovine. To je posljedica smanjenog potencijala upijanja vode nakon toplinske obrade drva.

Slična tendencija smanjenja fizikalnih svojstava i signifikantnost razlike srednjih vrijednosti pokazuje se za gustoću u apsolutno suhom stanju te za maksimalno radijalno, tangencijalno i volumno utezanje. Srednja vrijednost gustoće u apsolutno suhom stanju neobrađene bukovine veća je za 8,5\% od srednje vrijednosti gustoće u apsolutno suhom stanju toplinski obrađene bukovine. Srednja vrijednost maksimalnoga radijalnog utezanja neobrađene bukovine veća je za $7 \%$ od srednje vrijednosti maksimalnoga radijalnog utezanja toplinski obrađene bukovine i signifikantno se razlikuju. Sličan odnos pokazuje maksimalno tangencijalno utezanje, s tim da je srednja vrijednost maksimalnoga tangencijalnog utezanja neobrađene bukovine za 23,5 \% veća od srednje vrijednosti maksimalnoga tangencijalnog ute- 
....... Sinković, Govorčin, Sedlar: Usporedba fizikalnih svojstava neobrađene i toplinski...

Tablica 1. Prikaz statističkih vrijednosti fizikalnih svojstava neobrađene i toplinski obrađene bukovine.

Table 1. Survey of statistical values for physical properties of untreated and heat treated beech

\begin{tabular}{|c|c|c|c|c|c|c|c|c|c|c|c|c|}
\hline \multicolumn{5}{|c|}{ Neobrađena bukovina-Untreated beech } & \multicolumn{4}{c|}{ Toplinski obrađena bukovina - Heat treated beech } \\
\hline$\rho_{\mathrm{w}}$ & $\rho_{\mathrm{o}}$ & $W$ & $\beta_{\mathrm{r}}$ maks. & $\beta_{\mathrm{t}}$ maks. & $\beta_{\mathrm{v}}$ maks. & & $\beta_{\mathrm{v}}$ maks. & $\beta_{\mathrm{t}}$ maks. & $\beta_{\mathrm{r}}$ maks. & $W$ & $\rho_{\mathrm{o}}$ & $\rho_{\mathrm{w}}$ \\
\hline $\mathrm{g} / \mathrm{cm}^{3}$ & $\mathrm{~g} / \mathrm{cm}^{3}$ & $\%$ & $\%$ & $\%$ & $\%$ & & $\%$ & $\%$ & $\%$ & $\%$ & $\mathrm{~g} / \mathrm{cm}^{3}$ & $\mathrm{~g} / \mathrm{cm}^{3}$ \\
\hline 49 & 49 & 49 & 49 & 49 & 49 & $\mathrm{~N}$ & 65 & 65 & 65 & 65 & 65 & 65 \\
\hline 1,094 & 0,636 & 88 & 4,44 & 11,6 & 16,2 & MIN & 11,7 & 5 & 3,3 & 72 & 0,546 & 1,01 \\
\hline 1,144 & 0,680 & 105 & 5,78 & 12,6 & 17,9 & AVE & 15 & 10,2 & 5,4 & 91 & 0,627 & 1,084 \\
\hline 1,201 & 0,752 & 117 & 6,94 & 13,5 & 19,1 & MAX & 17 & 11,7 & 8,1 & 119 & 0,739 & 1,141 \\
\hline 0,0247 & 0,0347 & 8,9 & 0,62 & 0,43 & 0,65 & SD & 1,54 & 1,18 & 0,94 & 12,7 & 0,06 & 0,028 \\
\hline 0,0006 & 0,0012 & 79,7 & 0,38 & 0,19 & 0,43 & VAR & 2,36 & 1,4 & 0,88 & 160 & 0,004 & 0,0008 \\
\hline
\end{tabular}

Legenda: $\rho_{\mathrm{w}}$ - gustoća nakon 14-dnevnog potapanja u vodi, $\rho_{\mathrm{o}}$ - gustoća u apsolutno suhom stanju, $W$ - sadržaj vode nakon 14-dnevnog potapanja, $\beta_{\mathrm{r}}$ maks. - totalno radijalno utezanje, $\beta_{\mathrm{t}}$ maks. - totalno tangencijalno utezanje i $\beta_{\mathrm{v}}$ maks. - totalno volumno utezanje

Key: $\rho_{w}$ - density after a fortnight of water soaking, $\rho_{o}$ - density in absolutely dry condition, $W$ - water content after a fortnight of soaking, $\beta_{r}$ max - total radial shrinkage, $\beta_{t}$ max - total tangential shrinkage and $\beta_{v}$ max - total volume shrinkage

zanja toplinski obrađene bukovine. Srednja vrijednost maksimalnoga volumnog utezanja neobrađene bukovine veća je za 19,3 \% nego toplinski obrađene bukovine.

Sve navedene vrijednosti pokazuju da toplinski obrađena bukovina slabije upija vodu, ima manju gustoću i manja maksimalna utezanja od neobrađene. Toplinska obrada bukovine opravdava svoju svrhu jer su toplinskom obradom neobrađene bukovine njezina relativno nepovoljna maksimalna utezanja poboljšana, tj. znatno smanjena.

Na slikama 1. i 2. prikazan je odnos maksimalnoga radiajalnog utezanja te gustoće u apsolutno suhom stanju za neobrađenu i toplinski obrađenu bukovinu.

Na slikama 1. i 2. vidljivo je da se s porastom gustoće $u$ apsolutno suhom stanju neobrađene bukovine maksimalno radijalno utezanje smanjuje, uz zadovoljavajući koeficijent korelacije za drvo. Nasuprot tome, s porastom gustoće $\mathrm{u}$ apsolutno suhom stanju to- plinski obrađene bukovine maksimalno radijalno utezanje raste, uz zadovoljavajući koeficijent korelacije za drvo.

Slične zakonitosti vidljive su i za maksimalno volumno utezanje neobrađene i toplinski obrađene bukovine na slikama 3. i 4.

Statističke vrijednosti rezultata istraživanja fizikalnih svojstava neobrađene i toplinski obrađene grabovine prikazane su u tablici 2.

Prema Mann-Whitneyevu testu, srednje vrijednosti gustoće i sadržaja vode nakon potapanja neobrađene grabovine signifikantno su veće od srednjih vrijednosti gustoće i sadržaja vode nakon potapanja toplinski obrađene grabovine.

Srednja vrijednost sadržaja vode nakon potapanja neobrađene grabovine veća je za $12,5 \%$ od srednje vrijednosti sadržaja vode nakon potapanja toplinski obrađene grabovine. To je posljedica smanjenog potencijala upijanja vode nakon toplinske obrade drva.

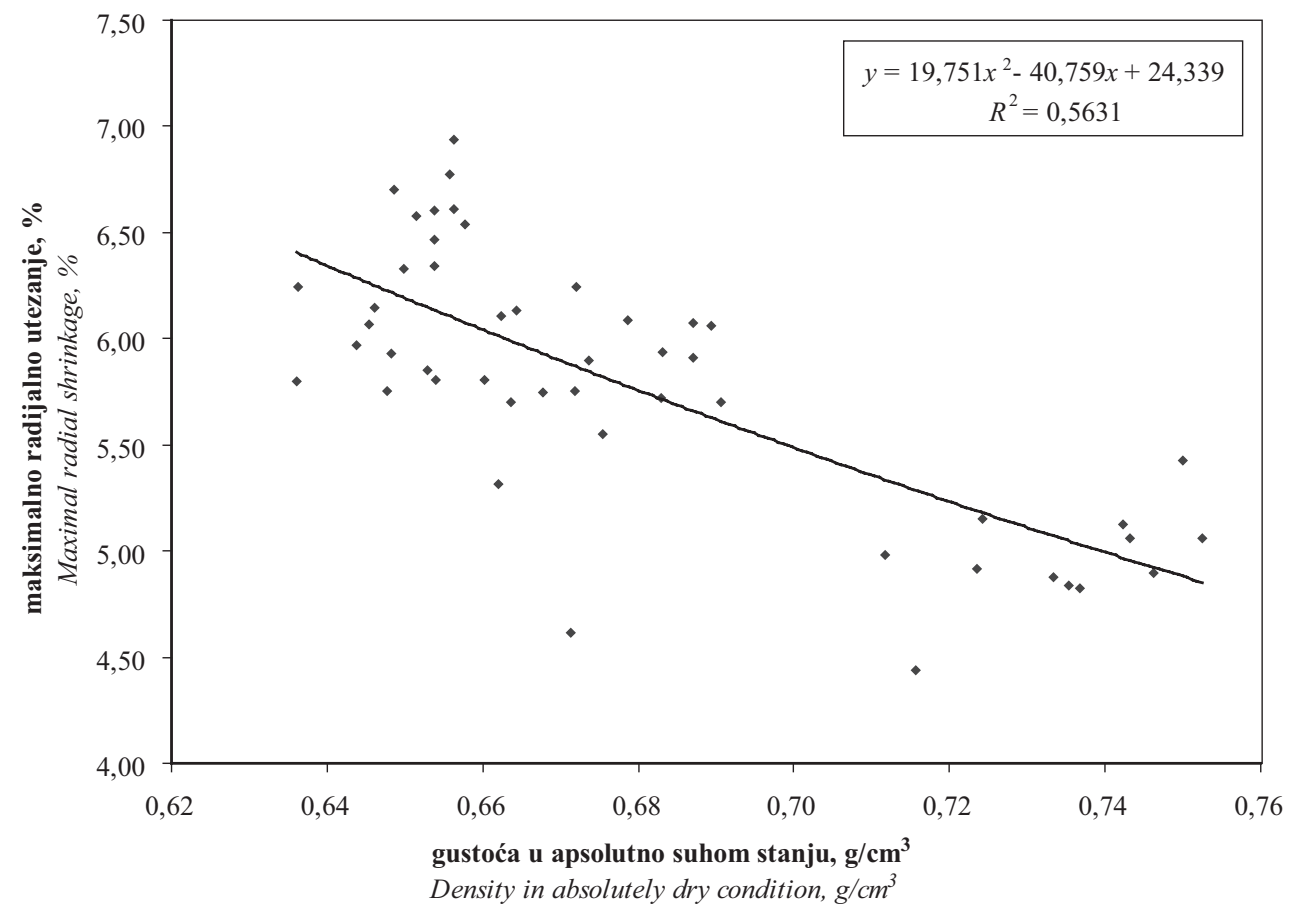

Slika 1. Odnos gustoće u apsolutno suhom stanju i maksimalnoga radijalnog utezanja neobrađene bukovine

Figure 1 Relationship between density in absolutely dry condition and maximum radial shrinkage for untreated beech wood 


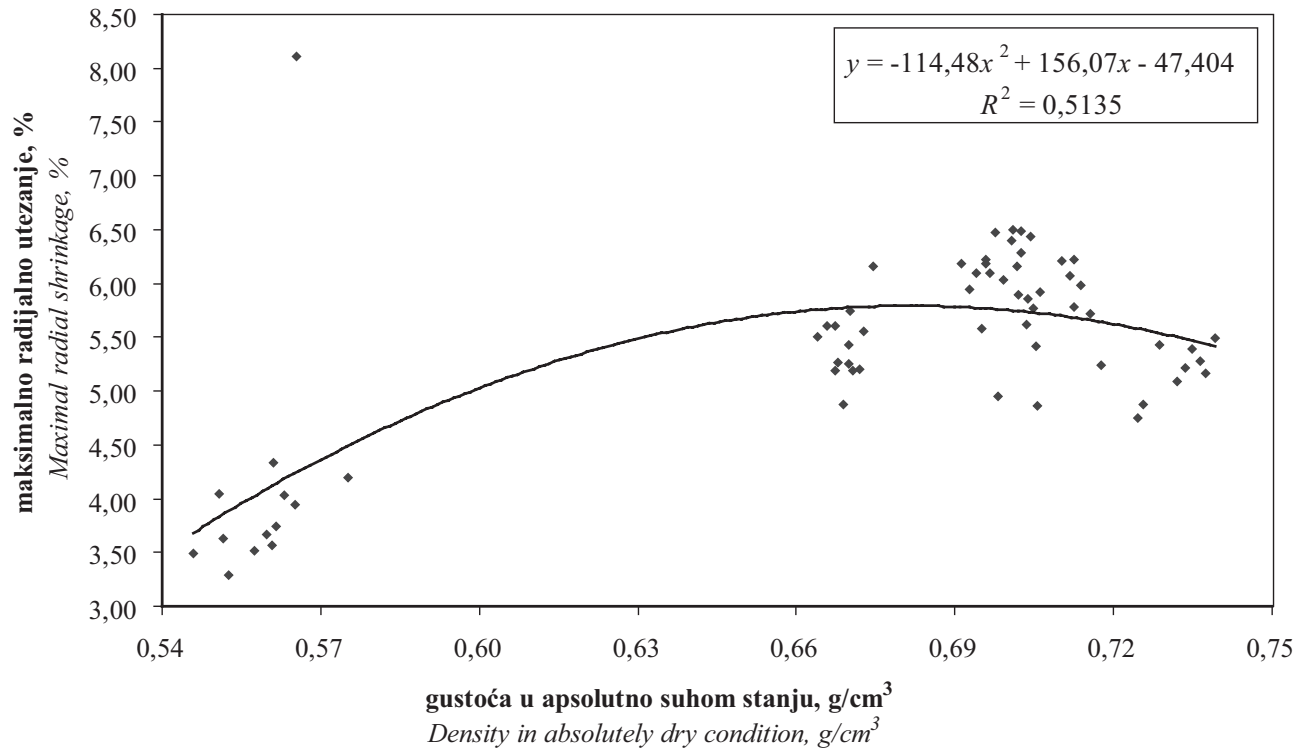

Slika 2. Odnos gustoće u apsolutno suhom stanju i maksimalnoga radijalnog utezanja toplinski obrađene bukovine

Figure 2 Relationship between density in absolutely dry condition and maximum radial shrinkage for heat treated beech

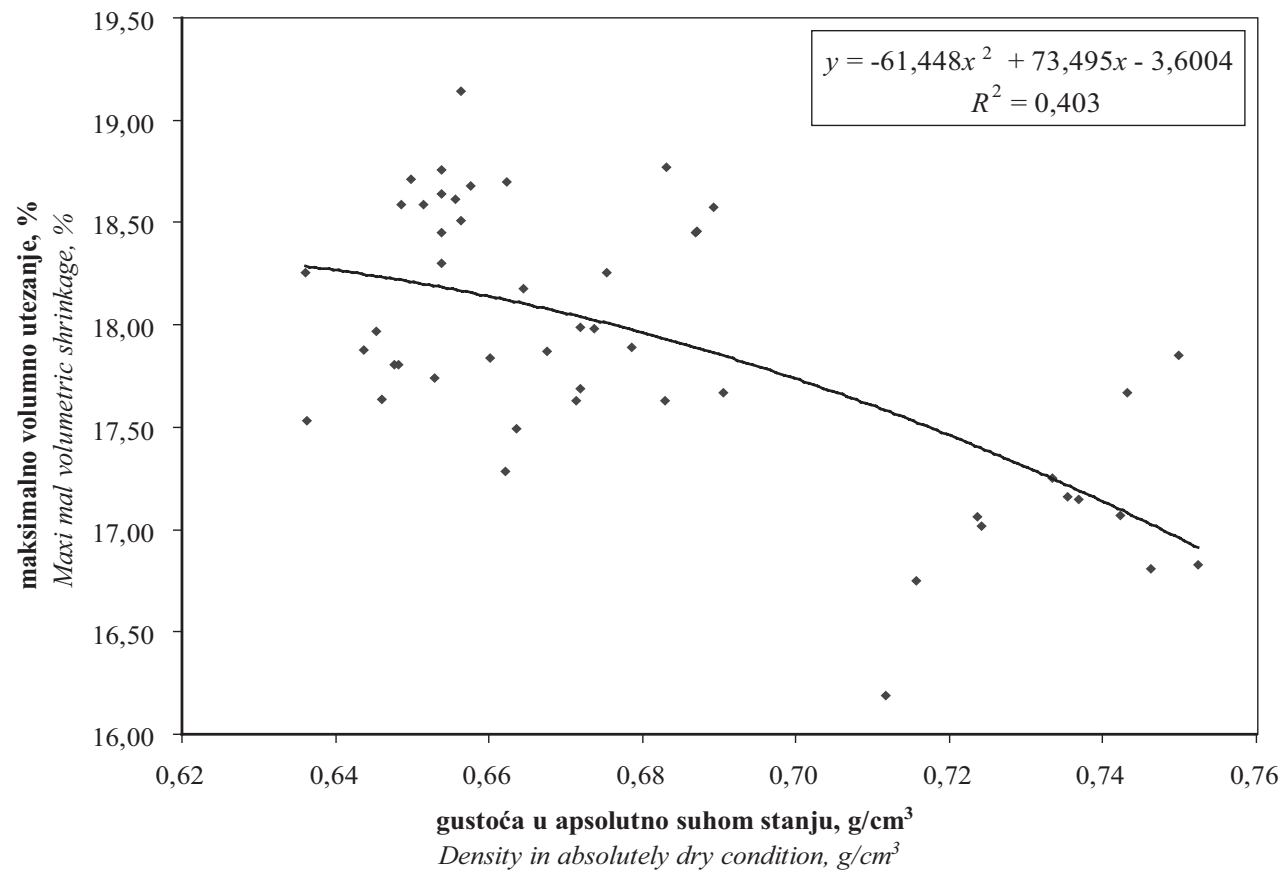

Slika 3. Odnos gustoće u apsolutno suhom stanju i maksimalnoga volumnog utezanja neobrađene bukovine

Figure 3 Relationship between density in absolutely dry condition and maximum volume shrinkage for untreated beech wood

Tablica 2. Prikaz statističkih vrijednosti za fizikalna svojstva neobrađene i toplinski obrađene grabovine

Table 2 Survey of statistical values for physical properties of untreated and heat treated hornbeam wood

\begin{tabular}{|c|c|c|c|c|c|c|c|c|c|c|c|c|}
\hline \multicolumn{4}{|c|}{$\begin{array}{c}\text { Neobradena grabovina } \\
\text { Untreated hornbeam }\end{array}$} & \multicolumn{5}{c|}{$\begin{array}{c}\text { Toplinski obradena grabovina } \\
\text { Heat treated hornbeam }\end{array}$} \\
\hline$\rho_{\mathrm{w}}$ & $\rho_{\mathrm{o}}$ & $W$ & $\beta_{\mathrm{r}}$ maks. & $\beta_{\mathrm{t}}$ maks. & $\beta_{\mathrm{v}}$ maks. & & $\beta_{\mathrm{v}}$ maks. & $\beta_{\mathrm{t}}$ maks. & $\beta_{\mathrm{r}}$ maks. & $W$ & $\rho_{\mathrm{o}}$ & $\rho_{\mathrm{w}}$ \\
\hline $\mathrm{g} / \mathrm{cm}^{3}$ & $\mathrm{~g} / \mathrm{cm}^{3}$ & $\%$ & $\%$ & $\%$ & $\%$ & & $\%$ & $\%$ & $\%$ & $\%$ & $\mathrm{~g} / \mathrm{cm}^{3}$ & $\mathrm{~g} / \mathrm{cm}^{3}$ \\
\hline 59 & 59 & 59 & 59 & 59 & 59 & $\mathrm{~N}$ & 30 & 30 & 30 & 30 & 30 & 30 \\
\hline 1,103 & 0,683 & 84 & 6,34 & 8,3 & 15,5 & MIN & 7,53 & 4 & 3,1 & 66 & 0,620 & 1,049 \\
\hline 1,125 & 0,716 & 90 & 8,02 & 9,86 & 17,1 & AVE & 8,57 & 5,3 & 3,6 & 80 & 0,666 & 1,092 \\
\hline 1,154 & 0,735 & 94 & 9,54 & 11,1 & 19,3 & MAX & 9,99 & 8,6 & 4,4 & 92 & 0,711 & 1,124 \\
\hline 0,01 & 0,0123 & 2,43 & 0,84 & 0,64 & 0,92 & SD & 0,65 & 0,92 & 0,31 & 6,38 & 0,03 & 0,02 \\
\hline 0,0001 & 0,0002 & 5,92 & 0,71 & 0,41 & 0,85 & VAR & 0,42 & 0,84 & 0,1 & 40,6 & 0,0009 & 0,0004 \\
\hline
\end{tabular}

Legenda: $\rho_{\mathrm{w}}$ - gustoća nakon 14-dnevnog potapanja u vodi, $\rho_{\mathrm{o}}$ - gustoća u apsolutno suhom stanju, $W$ - sadržaj vode nakon 14-dnevnog potapanja, $\beta \mathrm{r}$ maks. - totalno radijalno utezanje, $\beta \mathrm{t}$ maks. - totalno tangencijalno utezanje i $\beta \mathrm{v}$ maks. - totalno volumno utezanje

Key: $\rho_{w}$ - density after a fortnight of water soaking, $\rho_{\rho}$ - density in absolutely dry condition, $W$ - water content after a fortnight of soaking, $\beta r$ max - total radial shrinkage, $\beta$ t max - total tangential shrinkage and $\beta v$ max - total volume shrinkage 


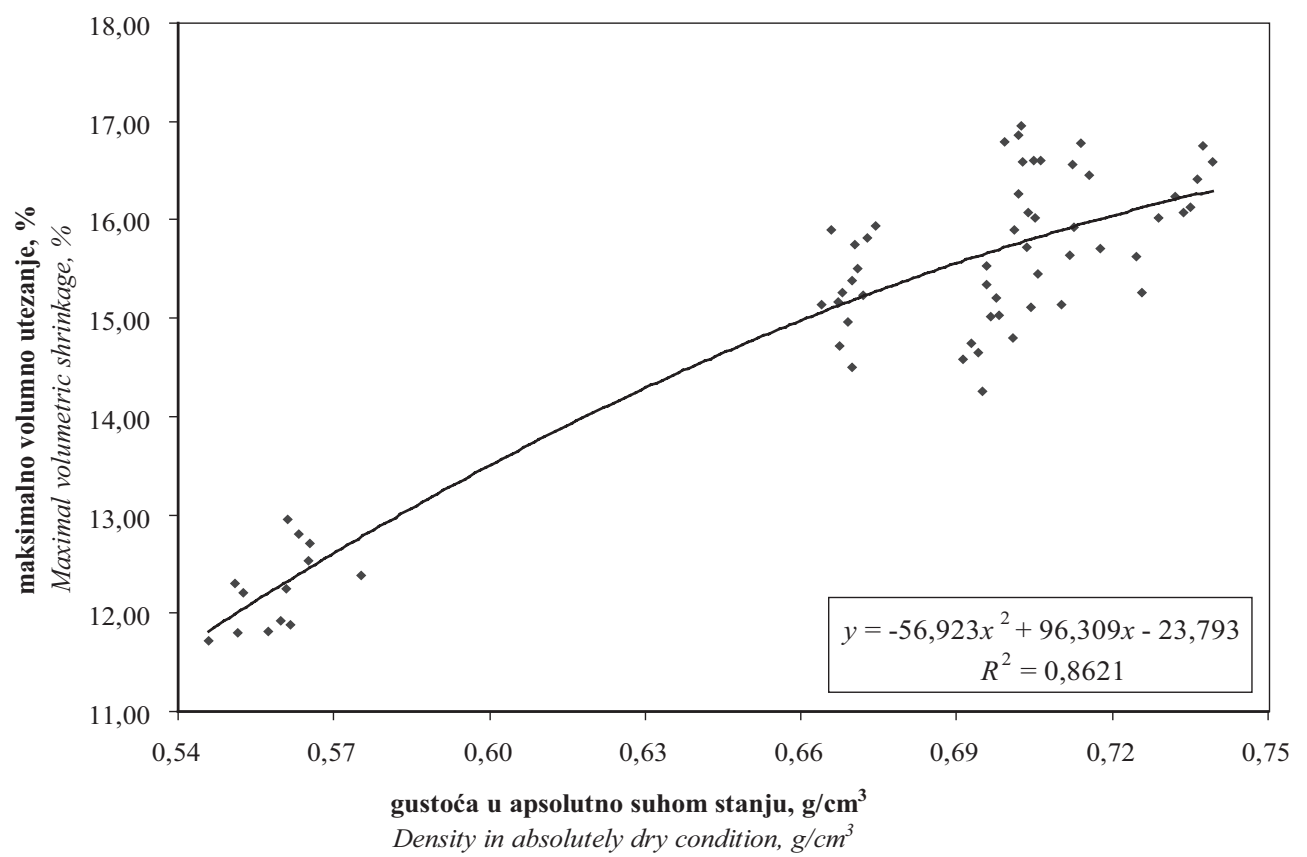

Slika 4. Odnos gustoće u apsolutno suhom stanju i maksimalnoga volumnog utezanja toplinski obrađene bukovine Figure 4 Relationship between density in absolutely dry condition and maximum volume shrinkage for heat treated beech wood

Slična tendencija smanjenja fizikalnih svojstava i signifikantnost razlike srednjih vrijednosti pokazuje se za gustoću u apsolutno suhom stanju te za maksimalno radijalno, tangencijalno i volumno utezanje. Srednja vrijednost gustoće u apsolutno suhom stanju neobrađene grabovine veća je za 7,5 \% od srednje vrijednosti toplinski obrađene grabovine. Srednja vrijednost maksimalnoga radijalnog utezanja neobrađene grabovine veća je za $123 \%$ od srednje vrijednosti maksimalnoga radijalnog utezanja toplinski obrađene grabovine i signifikantno se razlikuju. Sličan odnos pokazuje tangencijalno utezanje, s tim da je srednja vrijednost maksimalnoga tangencijal- nog utezanja neobrađene grabovine za $86 \%$ veća od paralelne srednje vrijednosti toplinski obrađene grabovine. Srednja vrijednost maksimalnoga volumnog utezanja neobrađene grabovine veća je za 99,5 \% od paralelne srednje vrijednosti toplinski obrađene grabovine.

Navedene vrijednosti pokazuju da toplinski obrađena grabovina slabije upija vodu, ima manju gustoću $\mathrm{u}$ apsolutno suhom stanju i manja maksimalna utezanja od neobrađene grabovine. Toplinska obrada grabovine opravdava svoju svrhu jer su toplinskom obradom neobrađene grabovine njezina izrazito nepovoljna maksimalna utezanja znatno poboljšana, tj. uvelike smanje-

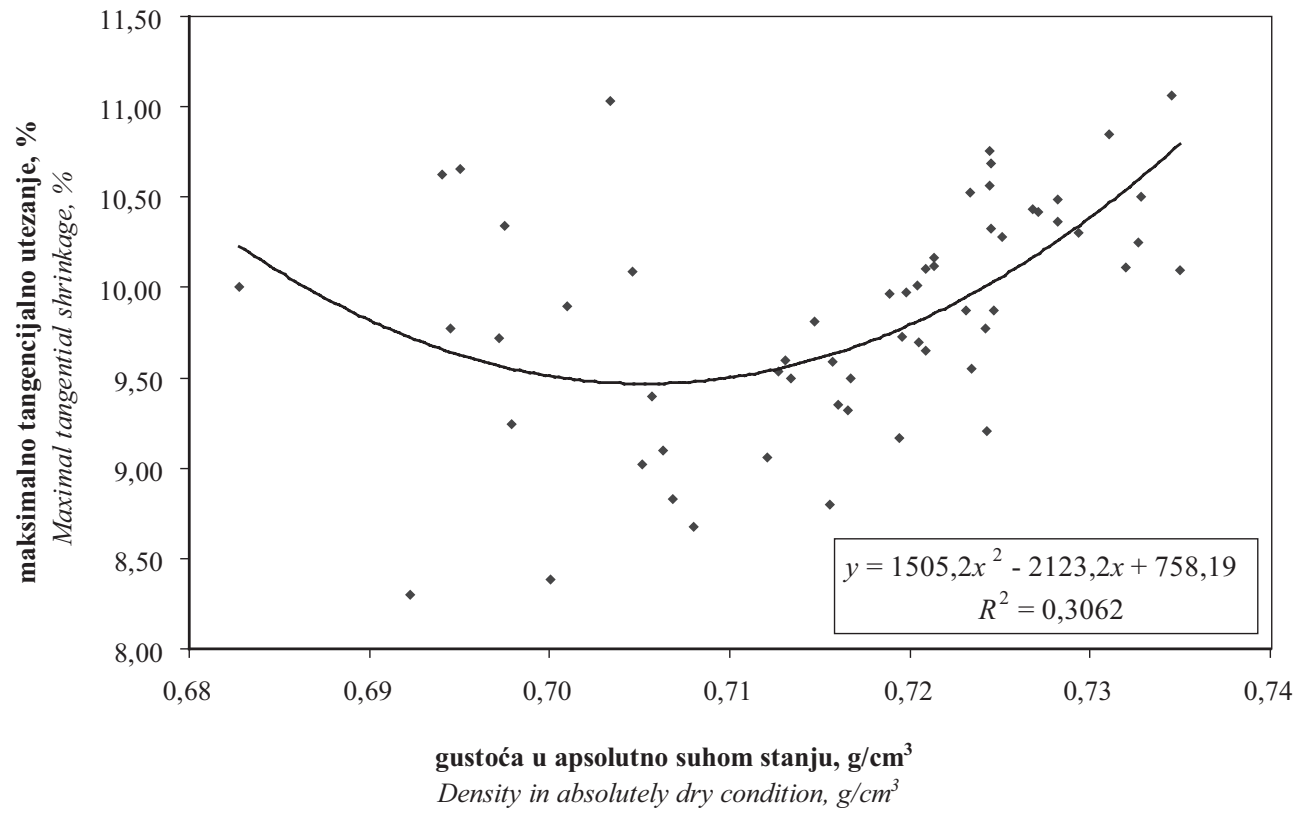

Slika 5. Odnos gustoće u apsolutno suhom stanju i maksimalnoga tangencijalnog utezanja neobrađene grabovine Figure 5 Relationship between density in absolutely dry condition and maximum tangential shrinkage for hornbeam wood 


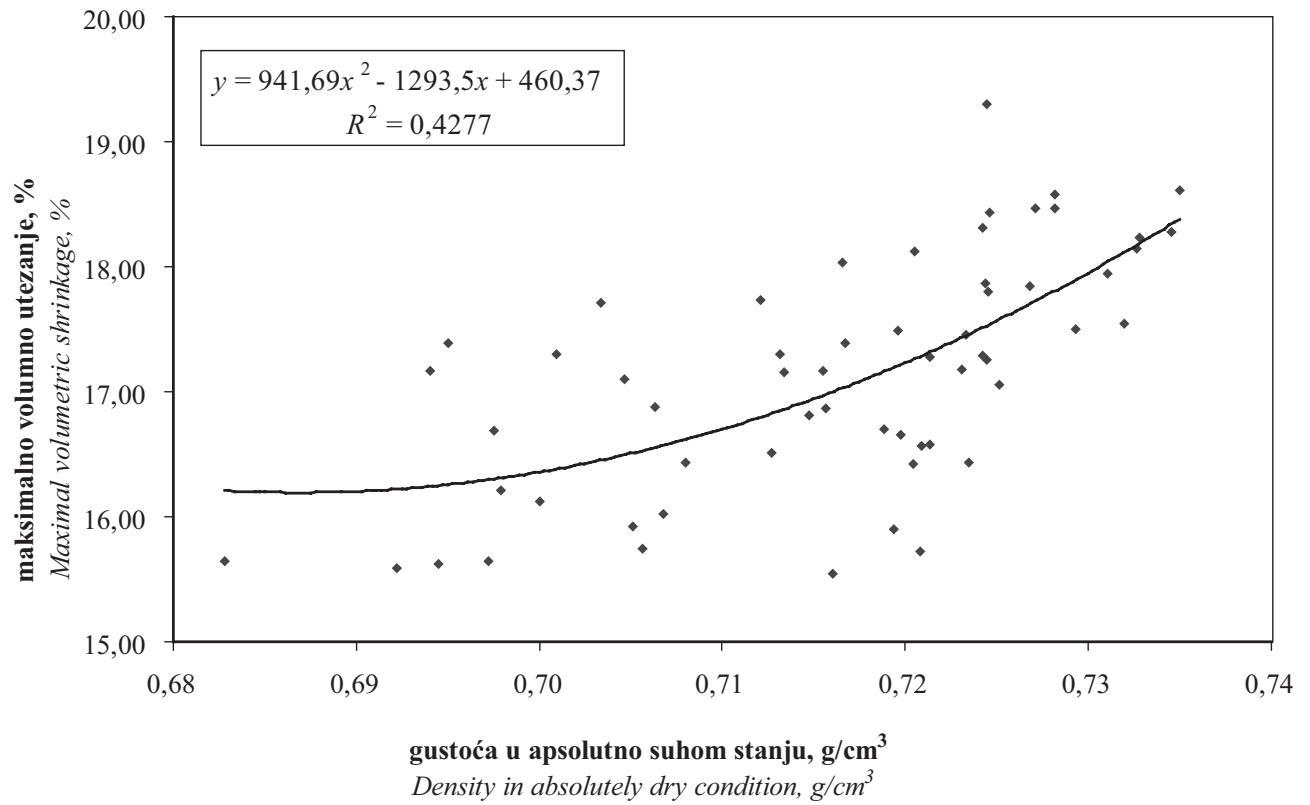

Slika 6. Odnos gustoće u apsolutno suhom stanju i maksimalnoga volumnog utezanja neobrađene grabovine

Figure 6 Relationship between density in absolutely dry condition and maximum volume shrinkage for hornbeam wood

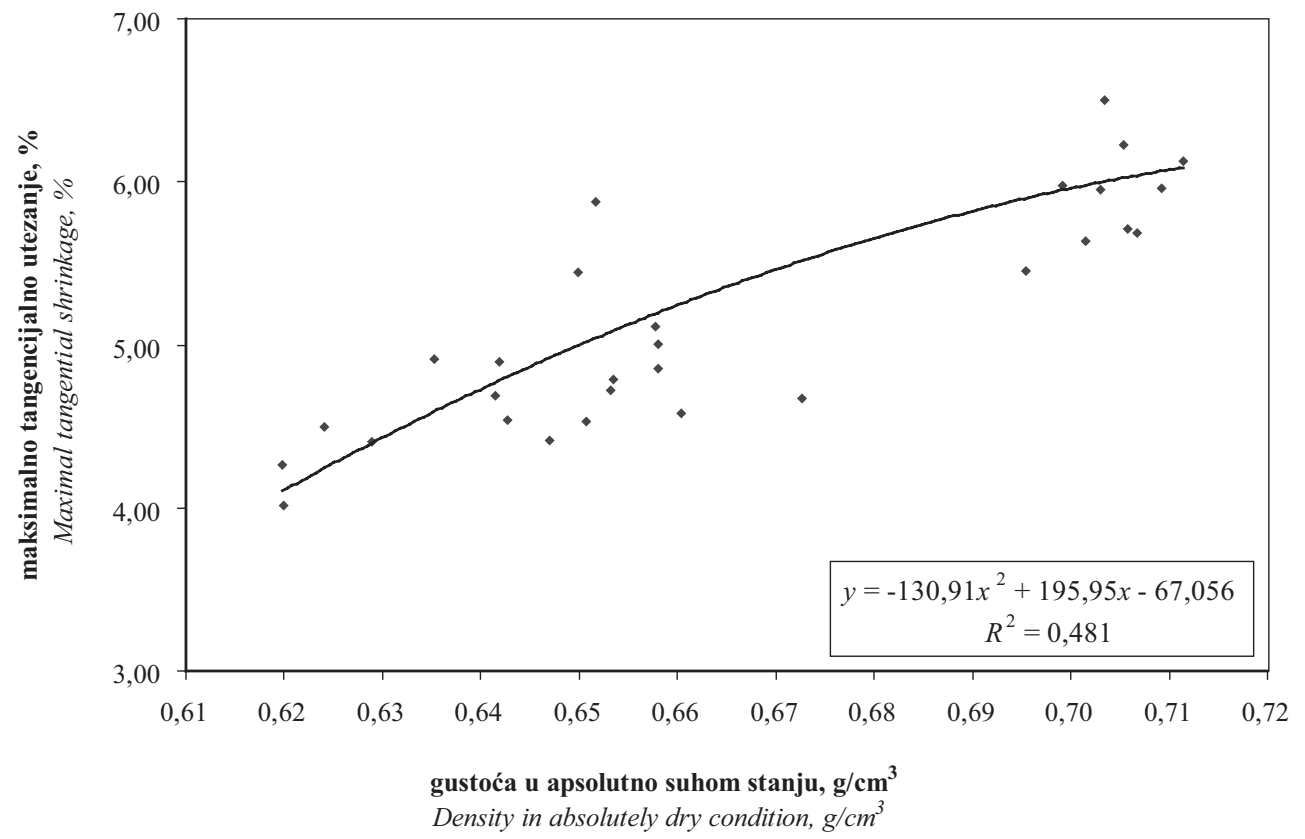

Slika 7. Odnos gustoće u apsolutno suhom stanju i maksimalnoga tangencijalnog utezanja toplinski obrađene grabovine Figure 7 Relationship between density in absolutely dry condition and maximum tangential shrinkage for heat treated hornbeam wood

na. Na slikama 5. i 6. prikazan je odnos maksimalnoga tangencijalnog i volumnog utezanja te gustoće u apsolutno suhom stanju za neobrađenu grabovinu.

Na slikama 5 - 8. vidljivo je da se s porastom gustoće u apsolutno suhom stanju povećavaju maksimalna utezanja u tangencijalnom smjeru i volumna utezanja neobrađene i toplinski obrađene grabovine. Koeficijenti korelacije podataka, s krivuljama koje pokazuju trend, također su zadovoljavajući za drvo. Takav opći trend nije u potpunosti jednak za sve prikazane odnose fizikalnih svojstava. Na slici 5. za odnos gustoće $\mathrm{u}$ apsolutno suhom stanju i maksimalnoga tangencijalnog utezanja neobrađene grabovine pri nižim je gustoćama zamjetan pad vrijednosti, nakon čega dolazi njegova porasta.

\section{ZAKLJUČCI 4 CONCLUSIONS}

Toplinskom obradm bukovine postignuto je očekivano smanjenje maksimalnih utezanja po smjerovima, kao i maksimalno volumno utezanje. Iznosi smanjenja srednjih vrijednosti maksimalnih utezanja toplinski obrađene bukovine u usporedbi s neobrađenom kreću se od 19,3 \% za maksimalno volumno utezanje i $23,5 \%$ za maksimalno tangencijalno utezanje do $7 \%$ za maksimalno radijalno utezanje.

Srednje vrijednosti maksimalnih utezanja neobrađene bukovine signifikantno se razlikuju od srednjih vrijednosti maksimalnih utezanja toplinski obrađene bukovine. Neobrađenoj je bukovini toplinskom obra- 


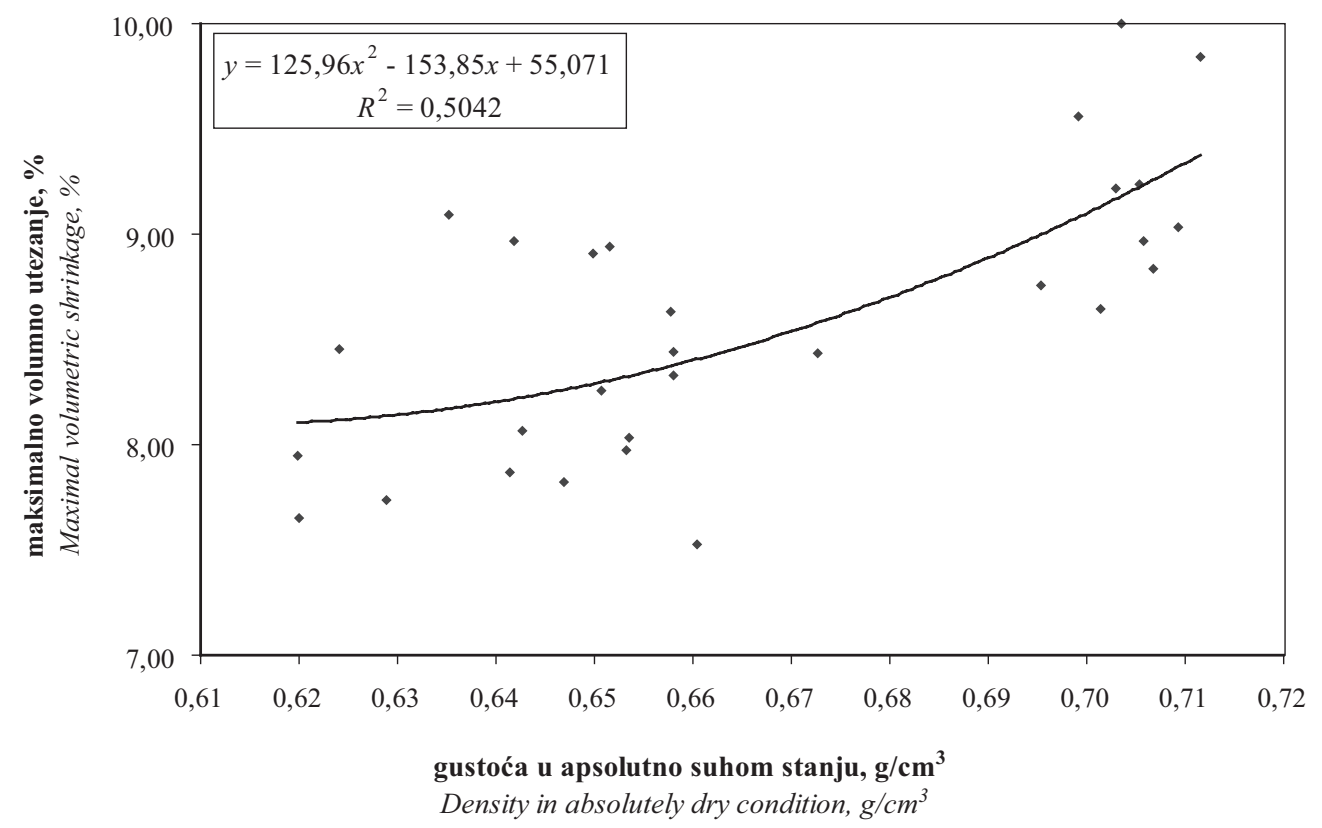

Slika 8. Odnos gustoće u apsolutno suhom stanju i maksimalnoga volumnog utezanja toplinski obrađene grabovine Figure 8 Relationship between density in absolutely dry condition and maximum volume shrinkage for heat treated hornbeam wood

dom također smanjena gustoća u apsolutno suhom stanju. Srednja vrijednost gustoće u apsolutno suhom stanju neobrađene bukovine veća je za $8,5 \%$ od srednje vrijednosti gustoće $u$ apsolutno suhom stanju toplinski obrađene bukovine $i$ te se vrijednosti signifikantno razlikuju. Srednja vrijednost gustoće nakon potapanja neobrađene bukovine veća je od iste vrijednosti toplinski obrađene bukovine, što vrijedi i za srednju vrijednost sadržaja vode, koji je nakon potapanja neobrađene bukovine za 15,4 \% veći nego u toplinski obrađene bukovine. Iz rezultata istraživanja vidljivo je da s porastom gustoće maksimalno radijalno utezanje u apsolutno suhom stanju u neobrađene bukovine pada. $\mathrm{U}$ toplinski obrađene bukovine s porastom gustoće $\mathrm{u}$ apsolutno suhom stanju maksimalno radijano utezanje raste. Ista je pojava uočena i za maksimalno volumno utezanje.

Neobrađena grabovina ima $12,5 \%$ veću srednju vrijednost sadržaja vode nakon potapanja nego toplinski obrađena grabovina, kao i veću srednju vrijednost gustoće u apsolutno suhom stanju, i to za 7,5 \%. Srednja vrijednost maksimalnog utezanja u radijalnom smjeru čak je za $123 \%$ veća za neobrađenu grabovinu nego za toplinski obrađenu grabovinu. Srednje vrijednosti maksimalnoga tangencijalnog utezanja neobrađene grabovine veće su za $86 \%$, a srednje vrijednosti maksimalnoga volumnog utezanja veće su za 99,5\% nego u toplinski obrađene grabovine. Sve srednje vrijednosti istraživanih svojstava neobrađene i toplinski obrađene grabovine signifikantno se razlikuju. Odnos gustoće u apsolutno suhom stanju i maksimalnih utezanja u tangencijalnom smjeru te maksimalnoga volumnog utezanja pokazuje da s porastom gustoće u apsolutno suhom stanju rastu i maksimalna utezanja u tangencijalnom smjeru i volumno.

Iz provedenog je istraživanja vidljivo da toplinski obrađena bukovina i grabovina imaju manje iznose srednjih vrijednosti maksimalnih utezanja u radijalnome i tangencijalnom smjeru, kao i volumno utezanje u usporedbi s neobrađenim drvom. Toplinskom je obradom tih dviju vrsta drva, a posebno grabovine, smanjen negativan faktor maksimalnih utezanja kao prepreka za primjenu u proizvodima od drva za koje je stabilnost dimenzija presudna.

\section{LITERATURA \\ 5 REFERENCES}

1. Bourgois, J.; Bartholin, M.C.; Guyonnet, R., 1989: Thermal treatment of wood: analysis of the obtained product. Wood Sci Technol, 23 (4): 303-310, http://dx.doi.org/10.1007/BF00353246

2. Hillis, W.E., 1984: High temperature and chemical effects on wood stability. Part 1, General considerations. Wood Sci Technol, 18: 281-293, http://dx.doi.org/10.1007/BF00353364

3. Kollmann, F.; Cote, W., 1968: Principles of Wood Science and Technology 1. Solid Wood. Springer, Heidelberg.

4. Kotilainen, R., 2000: Chemical Changes in wood during heating at $150-260^{\circ} \mathrm{C}$. Ph.D. Thesis, Javaskyla University, Finland.

5. Yildiz, S.; Colacoglu, G.; Yildiz, U.C.; Gezer, E.D.; Temiz, A., 2002: Efects of heat treatment of modulus of elasticity of beech wood. IRG/WP 02-40222.

6. Kumar, S., 1994: Chemical modification of wood. Wood Fiber Sci 26 (2): 270-280.

7. Militz, H.; Beckers, E.J.P.: Homan, W.J., 1997: Modification of solid wood: Research and potential. International Research Group in Wood Preservation, Document No IRG/WP 97-40098.

8. Rapp, A.O., 2001: Review on heat treatments of wood. COST Action E22 -Environmental of wood protection, Antibes (France) Rosset, P., Perre, P. and Girard, P.2204: Modification of mass transfer properties in poplar wood (P. Robusta) by a termal treatment at high temperature. Holz Roh-Werkst 62: 113-119. 
9. Rowell, R.M., 1983: Chemical modification of wood. Forest Prod Abstr 6 (12): 363-382.

10. Rowell, R.M., 1984: The chemistry of solid wood. American Chemical Society, Washington DC 84 , http://dx.doi.org/10.1021/ba-1984-0207

11. Stamm, A.J., 1946: Heat-stabilized wood. Ind Eng Chemistry 38 (6): 630-634, http://dx.doi.org/10.1021/ie50438a027

12. Stamm, A.J., 1956: Thermal degradation of wood and cellulose. Ind Eng Chem 48: 413-417, http://dx.doi.org/10.1021/ie51398a022

13. Stamm, A.R., 1964: Wood and cellulose science. Roland Press, USA, Chapter 19, pp 312-342.

14. Tjeerdsma, B.F.; Boonstra, M.; Pizzi, A.; Tekely, P.; Militz, H., 1998: Caracterisation of termally modified wood: molecular reasons for wood performance improvement. Holz Roh-Werkst 56 (3): 149-153, http://dx.doi.org/10.1007/s001070050287
15. Vernois, M., 2001: Heat treatment of wood in Francestate of the art. Proceedings of Special Seminar „Review on heat treatments of wood", Antibes, France.

16. Yildiz, S., 2002: Efects of heat treatment on water repellence and antiswelling efficiency of beech wood. IRG/ WP 02-40223.

\section{Corresponding address:}

Assoc. Prof. TOMISLAV SINKOVIĆ, Ph.D.

Department of Wood Science

Faculty of Forestry, University of Zagreb

Svetošimunska 25, p.p. 422

HR-10002 Zagreb, CROATIA

e-mail: tsinkovic@sumfak.hr 